\title{
Identifikasi Potensi Desa Wisata Kerta Payangan, Kabupaten Gianyar, Bali
}

Putu Aditya Dharma Arya Wiguna a, 1,I Nyoman Sukma Arida a, 2

1 aditya_dharma96@yahoo.com,2 sukma_arida@unud.ac.id.

a Program Studi Sarjana Destinasi Pariwisata, Fakultas Pariwisata, Universitas Udayana, Jl. Dr. R. Goris No 7, Denpasar, Bali 80232 Indonesia

\section{Abstract}

Tourist village of Kerta is one of village in Gianyar Regency that the tourist village which has tourism potential that range from cultural, natural, artificial and can be developed as a tourist destination or attraction for tourists. The purposes of this study is to know the identification of the potential of tourist village of Kerta.

The location of this research in the tourist village of Kerta, which has the location integrated with agriculture and tourism. The research in the tourist village of Kerta was conducted to discover the potential of the village (cultural, natural, and artificial potential of the tourist village). This research uses techniques of observation, interview, and documentation. The data analysist technique used is descriptive qualitative analysist. The purposive sampling technique using informants and use key informant.

The results of this reserch shows that there are a variety of potential tourist villages grouped into three parts, among others, the natural potential (indigenous forests, bamboo forests, paddy fields, citrus plantations and, organic plantations), cultural potential (site sarcophagus, Bali Aga traditions, and Alas Angker Temple), and artificial potential (Puncak Sari campground, tracking and cycling trails, and Munduk Asri). Also accordingly with the potential that is owned by the village and developed on an ongoing basis to achieve positive benefits for the life of the local community.

Keywords: Identification, Tourist Village, Kerta Village

\section{PENDAHULUAN}

Setiap destinasi selalu memiliki potensipotensi yang menjadikan sebuah destinasi mempunyai ciri khas dari suatu wilayah destinasi tersebut. Potensi-potensi tersebut biasanya terdapat pada suatu wilayah desa yang sangat berkaitan dengan adanya perkembangan kepariwisataan. Potensi dari Kabupaten Gianyar terdapat 12 sungai yang ada di wilayah Gianyar dan sebagian besar difungsikan sebagai irigasi persawahan, serta Gianyar memiliki 61 daya tarik wisata, sampai saat ini 17 yang sudah berkembang. Salah satunya yang diperhitungkan dalam perkembangan pariwisata yaitu Kecamatan Payangan. Payangan ini mempunyai suhu sejuk yang cenderung dingin sehingga sesuai untuk lahan pertanian dan agrowisata.

Dalam Kecamatan Payangan terdapat sebuah desa yang bernama Desa Kerta. Desa Kerta ini merupakan sebuah desa yang memiliki lahan yang cocok untuk pertanian. Desa Kerta ditetapkan sebagai Desa Wisata sejak tahun 2017 di wilayah Kabupaten Gianyar. Selain itu perkembangan kepariwisataan di Desa Kerta, adanya usaha swafoto "Munduk Asri", dan usaha perkemahan "Bumi Perkemahan Puncak Sari". Sedemikian berkembangnya Desa Kerta hingga sekarang sudah terdapat beberapa kunjungan dari wisatawan mancanegara maupun domestik. Selain itu dengan didukungnya akan banyaknya perkebunan dan pertanian milik masyarakat Desa Kerta menjadikan desa ini sebagai ladang untuk berkembangnya suatu daya tarik wisata.

Perkembangan kepariwisataan di suatu desa sangatlah diperlukan untuk keberlangsungan kehidupan dan kesejahteraan suatu desa tersebut. Berhubungan dengan prioritas dari Desa Kerta untuk mengedepankan pertaniannya dengan memanfaatkan sumber daya yang sangat melimpah. Pengembangan desa wisata di Desa Kerta adalah suatu pilihan yang sangat tepat dengan memanfaatkan kelebihan yang dimiliki oleh desa ini. Dalam proses pengembangan dalam memanfaatkan kelebihan yang dimiliki desa tersebut harus didukung akan adanya identifikasi potensi desa wisata yang masih bisa dikembangkan di Desa Kerta untuk perkembangan dan pertumbuhan perekonomian masyarakat di Desa Kerta yang lebih baik untuk kedepannya.

\section{KEPUSTAKAAN}

\subsection{Tinjauan Penelitian sebelumnya}

Adapun penelitian sebelumnya yang terkait, yang pertama adalah sebuah penelitian yang berkaitan dengan identifikasi potensi wisata di Desa Tihingan yang dilakukan oleh Suarka (2011). Acuan kedua merupakan penelitian yang berhubungan dengan identifikasi dan pengembangan potensi 
agrowisata di Desa Kerta yang dilakukan oleh Gunawan (2016).

\subsection{Tinjauan Konsep}

Dalam penelitian ini memakai empat konsep untuk menganalisis permasalahan, yaitu konsep pengembangan pariwisata (Swarbrooke 1996;99). Dalam penelitian ini pengembangan yang dimaksudkan adalah pada pengembangan identifikasi potensi Desa Wisata Kerta.

Konsep potensi wisata (Mariotti dalam Yoeti, 1996:172). Dalam penelitian ini konsep potensi wisata dibagi menjadi tiga bagian yang terdiri dari alam, budaya, dan buatan yang diperoleh di Desa Wisata Kerta.

Konsep desa wisata (Nuryanti, Wiendu dalam Anom dan Suryawan, 2016). Konsep komponen pariwisata merupakan penggolongan potensi wisata yang dimilki Desa Wisata Kerta dengan konsep 4A, komponen potensi wisata tersebut terdiri dari attraction, accessibility, amenity dan ancilliary (Cooper dkk, 1995).

\section{METODE PENELITIAN}

Penelitan ini berlokasi di Desa Wisata Kerta, Kecamatan Payangan, Kabupaten Gianyar, Provinsi Bali. Desa Wisata Kerta mempunyai potensi wisata yang didukung oleh kawasan agropolitan yang berkaitan dengan pariwisata. Jenis data dipakai berupa:

1) Data kualitatif, (berupa data identifikasi potensi alam, budaya, dan buatan Desa Wisata Kerta).

2) Data kuantitatif, (seperti luas wilayah di Desa Wisata Kerta).

Teknik pengumpulan data yang dipakai:

1) Observasi, (melakukan pengamatan mengenai potensi wisata Desa Wisata Kerta).

2) Wawancara, (dengan Kepala Desa Kerta terkait potensi wisata Desa Wisata Kerta).

Sumber data yaitu:

1) Data primer, (berupa potensi wisata Desa Wisata Kerta).

2) Data sekunder (berupa data monografi Desa Wisata Kerta).

Teknik analisis data, memakai teknik analisis deskriptif kualitatif.

\section{HASIL DAN PEMBAHASAN}

Bedasarkan hasil dilapangan, dapat diperoleh hasil berupa Identifikasi Potensi Desa Wisata Kerta. Potensi yang diperoleh dibedakan menjadi tiga bagian yang terdiri dari potensi alam, potensi budaya, dan potensi buatan.

\subsection{Potensi Alam}

Adapun potensi alam yang ada di Desa

Wisata Kerta antara lain terdiri dari Hutan Adat, Hutan Bambu, Persawahan, Perkebunan Jeruk, dan Perkebunan Organik.

\subsubsection{Potensi Hutan Adat}

Hutan yang tersebar di Desa Wisata Kerta bisa dikatakan sangat luas daerahnya. Di Desa Wisata Kerta terdapat hutan milik masyarakat (hutan rakyat) maupun hutan milik Banjar Adat (hutan adat). Hutan rakyat merupakan hutan yang ditanami secara sengaja untuk keperluan bahan baku bangunan, kerajiinan maupun untuk keperluan komersil. Sedangkan hutan adat adalah hutan milik adat yang telah ada sejak dahulu. Hutan adat sangat identik dengan keramat dan cerita mistis sehingga keberadaannya sangat dijaga dan dilestarikan oleh masyarakat adat desa. Di Desa Wisata Kerta terdapat hutan adat yang cukup luas tersebar di delapan desa pakraman. Hutan adat yang paling luas dan dengan kondisi yang masih sangat alami dan lestari berada di daerah Desa Pakraman Pilan. Di dalam hutan tersebut terdapat tempat suci atau Pura yang sangat sederhana tapi sangat dikeramatkan oleh masyarakat desa. Pura tersebut merupakan Pura Dalem Pingit. Pura ini merupakan pura yang dikeramatkan oleh masyarakat desa dengan tujuan bahwa hutan yang ada disekitar pura memiliki nilai magis sehingga tidak sembarangan orang bisa mengambil atau menebang pepohonan yang ada.

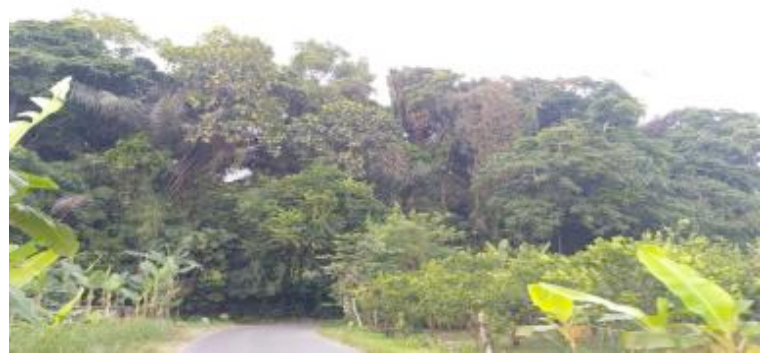

Gambar 4.1 Hutan Adat Desa Kerta Sumber : Hasil Penelitian, 2018

\subsubsection{Potensi Hutan Bambu}

Hutan bambu yang terdapat di Desa Wisata Kerta terbilang cukup luas mencapai ratusan hektar dan terdiri dari berbagai macam jenis bambu. Tumbuhan ini memiliki perakaran 
yang relative kuat dan banyak sehingga cocok ditanami di lahan yang kritis dan miring. Hutan bambu ini juga banyak terdapat pada daerah aliran sungai dan sumber air sebagai tanaman konservasi sehingga tampak menyatu dengan mata air dan aliran sungai yang ada.

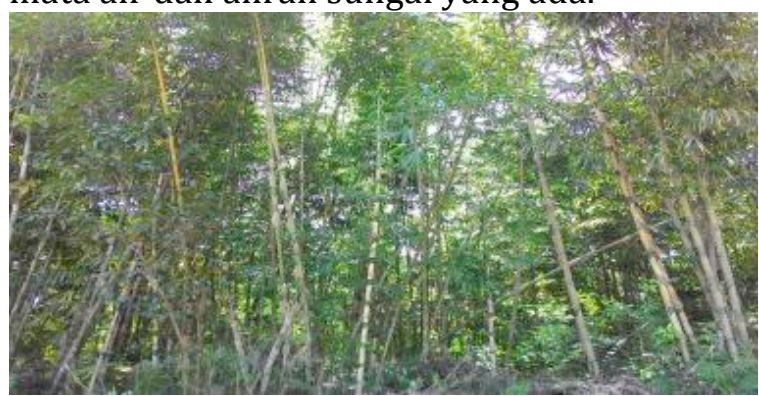

Gambar 4.2 Hutan Bambu Desa Kerta

Sumber : Hasil Penelitian, 2018

Di Desa Wisata Kerta bambu lebih banyak digunakan untuk keperluan keagamaan, bahan kerajinan, tanaman konservasi, dan umbul-umbul serta sebagai bahan makanan terutama rebungnya. Hutan bambu di Desa Wisata Kerta memiliki potensi wisata yang menarik perhatian dari segi hutan yang indah, luas dan hijau menciptakan suasana yang sejuk dan damai bagi wisatawan yang berkunjung.

\subsubsection{Potensi Persawahan}

Persawahan pada umumnya sangat diidentikkan dengan bentangan sawah yang indah dan hijau serta yang berterassering (bertingkat-tingkat). Keberadaan sawah merupakan kekayaan alam yang patut disyukuri karena selain sebagai penyedia kebutuhan pangan pokok masyarakat, khususnya beras, sawah juga merupakan salah satu daya tarik wisata sekaligus pendukung kepariwisataan.

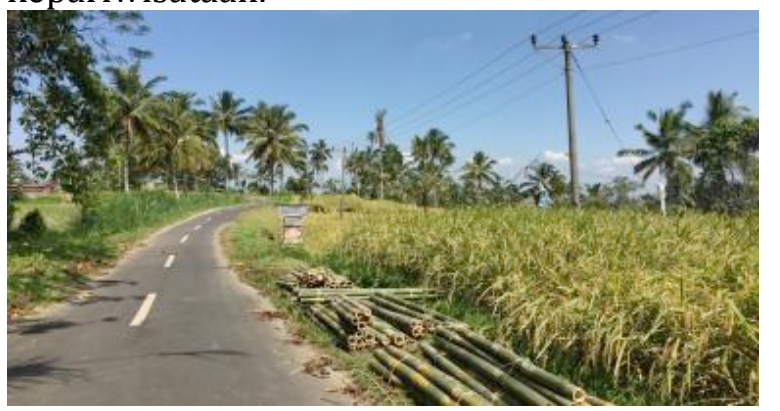

Gambar 4.3 Area Persawahan Desa Kerta

Sumber : Hasil Penelitian, 2018

Di Desa Wisata Kerta sangat banyak terdapat area persawahan tersebar di beberapa wilayah Desa Kerta meliputi subak-subak yang terdapat disekitarnya antara lain :

a) Subak Abian terdiri dari 5 subak yaitu :
1) Subak Abian Gunung Sari berada di Banjar Margatengah

2) Subak Abian Wana Sari berada di Banjar Penyabangan

3) Subak Abian Arta Wiguna berada di Banjar Bunteh

4) Subak Abian Giri Amerta berada di Banjar Pilan

5) Subak Abian Kerta Sari berada di Banjar Kerta

b) Subak Yeh terdiri dari 5 subak yaitu:

1) Subak Puseh berada di Banjar Bunteh

2) Subak Pengalu berada di Banjar Kerta

3) Subak Telaga Genten berada di Banjar Kerta

4) Subak Tirta Petak berada di Banjar Saren

5) Subak Amerta Nadi berada di Banjar Penyabangan

\subsubsection{Potensi Perkebunan Jeruk}

Perkebunan jeruk yang dimiliki oleh Desa Wisata Kerta termasuk cukup besar dan tersebar di wilayah desa. Berdasarkan data tahun 2014 sudah terdapat 226 hektar tanaman jeruk di Desa Wisata Kerta. Perkembangan perkebunan jeruk sangat memberikan dampak positif bagi perekonomian masyarakat desa. Dari segi pendapatan selalu mengalami peningkatan yang cukup signifikan dan menjadi sumber sumbangan terbesar dari produksi jeruk di Desa Wisata Kerta. Jenis jeruk yang dibudidayakan merupakan jenis Siem yang memiliki tingkat produktivitas yang tinggi dan cocok dikembangkan di daerah Desa Wisata Kerta.

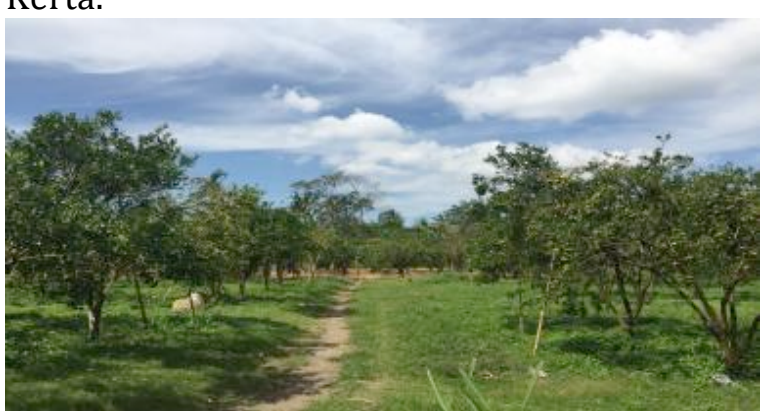

Gambar 4.4 Area Perkebunan Jeruk Desa Kerta Sumber : Hasil Penelitian, 2018

Aktivitas yang terdapat dalam area perkebunan jeruk yang berupa pembuatan bibit, penanaman, panen atau petik jeruk serta produk jeruk lainnya. Hal-hal tersebut yang dikembangkan menjadi salah satu bagian dari potensi Desa Wisata Kerta. 


\subsubsection{Potensi Perkebunan Organik}

Perkebunan organik yang berada di Desa Wisata Kerta merupakan milik salah satu pengusaha yang mengedepankan kepada komoditi sayuran. Komoditi sayuran ini sudah sangat memberi andil besar bagi perekonomian masyarakat.

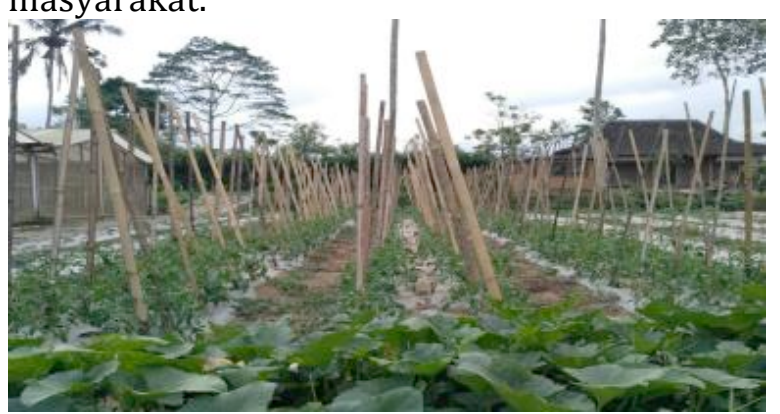

Gambar 4.5 Area Perkebunan Organik Desa Kerta

Sumber : Hasil Penelitian, 2018

Dari segi jenis sayuran yang dibudidayakan di wilayah perkebunan organik ini antara lain berupa jenis kacang-kacangan, tomat, cabai, sawi putih, kubis, terong dan tanaman sayuran lainnya. Dalam proses penanaman di perkebunan organik menggunakan bibit-bibit terbaik dan tanpa menggunakan pupuk-pupuk buatan dan pestisida sintetis (kimia) sehingga bisa menekan pencemaran tanah dan air disekitar wilayah perkebunan organik. Berhubungan dengan hal tersebut dalam hal penanganan hama, penyakit dan gulma dilakukan dengan menggunakan cara pengendalian mekanis, penggunaan pestisida nabati, penggunaan musuh alami serta melakukan rotasi tanaman. Di perkebunan organik ini menggunakan sistem panen mingguan sehingga dapat memperoleh hasil panen dengan jumlah yang konsisten di setiap harinya. Adapun persentase kegagalan dalam perkebunan organik ini sekitar $25 \%$ dikarenakan faktor kelembaban dan jamur. Diharapkan perkebunan organik ini dijadikan sebagai percontohan kepada masyarakat petani di Desa Wisata Kerta untuk mengembangkan perkebunan organik kedepannya.

Bunga potong ini juga mempunyai daya tahan atau daya simpan lebih tahan lama dibandingkan dengan jenis bunga lainnya. Di Desa Wisata Kerta sudah dikembangkan lebih dari 30 varietas bunga potong jenis heliconia yang didominasi dengan warna merah, merah muda, kuning, hijau, dan jingga, namun tidak sedikit jenis bunga potong ini memiliki warna kombinasi dari warna-warna tersebut. Adapun hasil perkebunan bunga potong ini didistribusikan ke daerah Ubud, Sanur, dan Kuta. Dengan kisaran harga perbatangnya sebesar Rp 3.000,- s/d Rp 5.000,- tergantung jenis bunga potongnya. Bunga potong di Desa Wisata Kerta banyak dimanfaatkan untuk keperluan upacara keagamaan, ulang tahun organisasi, dekorasi kegiatan, maupun untuk kegiatan pariwisata. Berhubungan dengan perkembangan kepariwisataan di Desa Wisata Kerta, bunga potong menjadi pembuka peluang dalam pengembangan daya tarik wisata petik bunga, merangkai bunga dan menjadi salah satu rute dalam jalur tracking yang ada di Desa Wisata Kerta.

\subsection{Potensi Budaya}

Adapun potensi budaya yang terdapat di Desa Wisata Kerta antara lain terdiri dari Situs Purbakala Sarkofagus, Tradisi Bali Aga, dan Pura Alas Angker.

\subsubsection{Potensi Situs Purbakala Sarkofagus}

Menurut pengelola situs sarkofagus I

Ketut Suaka, setelah proses pembongkaran pada tahun 1974, sering terjadi kejadian aneh seperti meninggalnya penduduk secara tidak wajar, segala yang ditanam tidak dapat tumbuh dan berproduksi secara normal. Sejak saat itu penduduk mengadakan upacara ngaben khusus, yaitu upacara Atma Wedana yang diperuntukan bagi orang meninggal yang sudah sangat lama. Upacara ini dilaksanakan karena masyarakat yakin bahwa kejadian aneh yang sering terjadi, disebabkan oleh pembongkaran sarkofagus tersebut tanpa diiringi dengan upacara. Untuk menghormati dan memuja leluhur yang berstana di Pura Kawitan Desa tersebut, penduduk setempat melakukan upacara (piodalan) setiap enam bulan sekali pada Saniscara Pahing Ukir selama sehari.

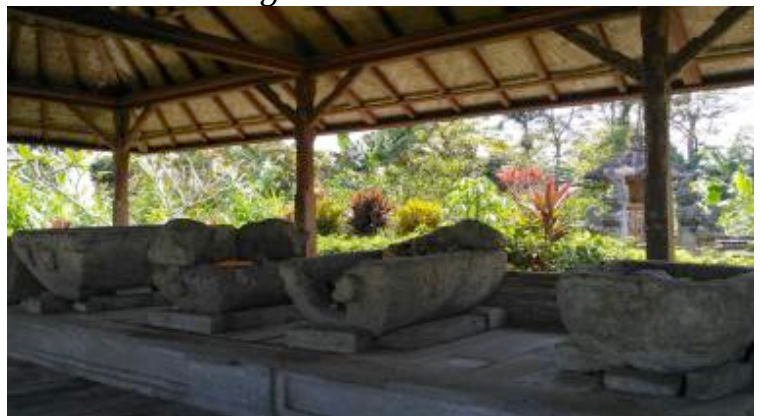

Gambar 4.6 Kondisi Sarkofagus Desa Kerta Sumber : Hasil Penelitian, 2018 
Dalam perkembangannya hingga saat ini situs sarkofagus sudah mengalami penataan dan renovasi mulai dari tahun 1981 dan tahun 1993. Menurut I Ketut Suaka peti batu atau sarkofagus yang ada di Desa Wisata Kerta merupakan termasuk dalam peti batu pada zaman termuda yaitu zaman megalitikum. Hingga saat ini isi dari dalam sarkofagus sendiri hanya tinggal sedikit, tidak banyak saat pertama kali ditemukannya dikarenakan pada saat pembongkaran adanya oknum-oknum yang mengambilnya secara disengaja. Berhubungan dengan ditetapkannya Desa Kerta sebagai Desa Wisata, situs sarkofagus menjadi salah satu tujuan singgah yang kadang dikunjungi wisatawan saat melakukan kegiatan tracking maupun cycling.

\subsubsection{Potensi Tradisi Bali Aga}

Di Desa Wisata Kerta ada empat desa pakraman, yang menganut tradisi pra Majapahit, yaitu tradisi Bali Aga, dari delapan desa pakraman yang ada di Desa Wisata Kerta. Empat desa pakraman tersebut antara lain Desa Margatengah, Desa Pilan, Desa Seming, dan Desa Penyabangan. Dimana Bali Aga merupakan orang-orang bauran antara masyarakat Bali Mula atau orang asli Bali yang merupakan keturunan orang-orang Austronesia dengan masyarakat Aga yang merupakan pengikut dari Ida Rsi Markandya dalam melakukan perjalanan menyebarkan agama Hindu di Bali. Pada umumnya dalam tradisi Bali Aga dipimpin oleh Kebayan (tengen/kanan) dan Kebau (kiwe/kiri) yang disebut dengan pelayan umat. Kanan dan kiri (tengen dan kiwe) ini diibaratkan sebagai bagian tubuh manusia yang terdiri dari dua hal yaitu kanan dan kiri, baik dari bagian kepala hingga kaki sehingga hal tersebut bertujuan akan adanya suatu keseimbangan.

Selain sistem kepemimpinan Bali Aga yang terdapat di Desa Wisata Kerta, terdapat juga arsitektur yang menunjukkan bahwa Desa Wisata Kerta ini termasuk dalam Desa Bali Aga terutama pada Desa Pakraman Margatengah. Di Desa Pakraman Margatengah terdapat arsitektur rumah warga yang menggunakan bahan tanah liat sebagai bahan dasar pembangunan rumah warga. Dalam perkembangannya hingga sekarang telah terjadinya beberapa perubahan dalam arsitektur bangunan tradisional menjadi bangunan modern. Hal ini dikarenakan adanya beberapa bangunan-bangunan dengan bahan tanah liat yang sudah mulai lapuk dan hancur. Hingga saat ini hanya terdapat beberapa rumah warga yang masih mempertahankan bentuk bangunan yang menggunakan bahan tanah liat sebagai bahan dasarnya seperti tembok-tembok pagar rumah warga di Desa Pakraman Margatengah.

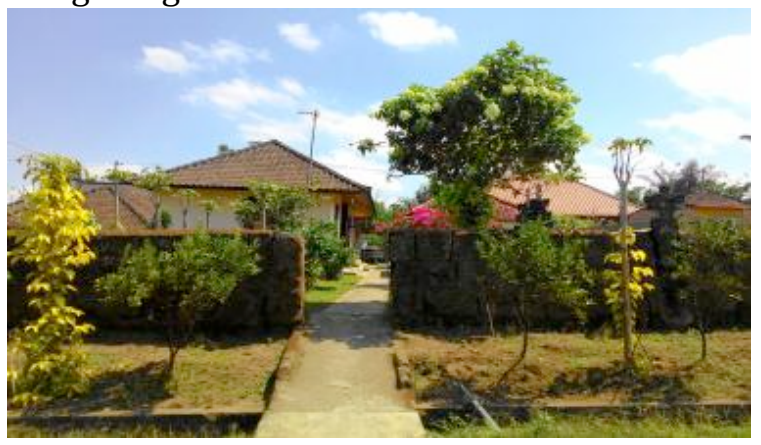

Gambar 4.7 Arsitektur Bangunan Tradisional Desa Kerta

\section{Sumber : Hasil Penelitian, 2018}

Keunikan yang terdapat dalam tradisi Bali Aga ini dapat menjadi daya tarik wisata dalam segi nilai historis yang unik dimiliki oleh Desa Wisata Kerta. Hal itu didukung dengan eksistensinya tradisi Bali Aga tersebut hingga sekarang masih bertahan melawan perkembangan zaman dan sampai saat ini keberadaannya masih sangat kuat atau kental.

\subsubsection{Potensi Pura Alas Angker}

Pura Alas Angker merupakan salah satu pura yang memiliki nilai sejarah yang tinggi. Berdasarkan sejarah Desa Kerta diceritakan kisah kedatangan seorang Maha Rsi yang bernama Rsi Markandya, disamping bergelar sebagai Rsi, beliau juga dikenal sebagai Aksitektur dan sebagai Pendeta.

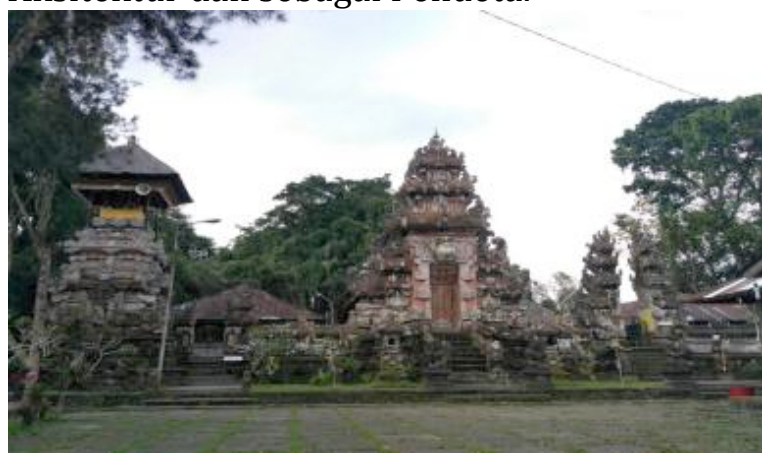

Gambar 4.8 Kondisi Pura Alas Angker

Sumber : Hasil Penelitian, 2018

Pura Alas Angker sudah mengalami renovasi sebanyak 2 kali dikarenakan adanya beberapa kerusakan pada salah satu bangunan 
pura serta pemegaran area untuk parkir. Piodalan di Pura Alas Angker dilaksanakan setiap 6 bulan sekali pada wuku wugu. Selama perkembangannya pura ini lebih banyak dikunjungi oleh masyarakat lokal dan masyarakat dari luar daerah Desa Wisata Kerta untuk melakukan persembahyangan.

\subsection{Potensi Buatan}

Adapun potensi buatan yang terdapat di Desa Wisata Kerta antara lain terdiri dari Bumi Perkemahan Puncak Sari, Jalur Tracking dan Cycling, dan Wisata Munduk Asri.

\subsubsection{Bumi Perkemahan Puncak Sari}

Bumi Perkemahan Puncak Sari merupakan salah satu fokus pengembangan pendukung dari perkembangan Desa Wisata Kerta. Bumi perkemahan yang lokasinya berada di wilayah Banjar Pilan ini telah dikembangkan dari tahun 2016, mulai dari pembukaan lahan dan penataan serta pengembangan fasilitas yang dimiliki oleh Bumi Perkemahan Puncak Sari. Adapun fasilitas yang dimiliki oleh bumi perkemahan ini antara lain berupa fasilitas toilet, dapur, wantilan serta penerangan yang sudah sangat memadai. Begitu juga dengan akses menuju Bumi Perkemahan Puncak Sari saat ini sudah mengalami perbaikan sehingga akses yang digunakan sudah sangat baik.

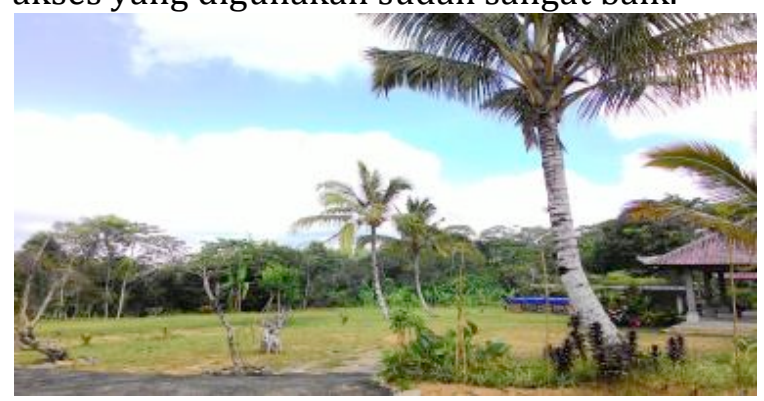

Gambar 4.9 Bumi Perkemahan Puncak Sari

Sumber : Hasil Penelitian, 2018

Keberadaan Bumi Perkemahan Puncak Sari ini didukung dengan kegiatan-kegiatan yang dilaksanakan seperti out bound, acara perkemahan sekolah maupun kampus, sebagai tempat diskusi atau pertemuan resmi dan lain sebagainya. Dalam perkembangan Desa Wisata Kerta kedepannya, bumi perkemahan ini akan dijadikan sebagai tempat istirahat untuk wisatawan yang melakukan aktivitas tracking maupun cycling serta dijadikan sebagai tempat menginap wisatawan dengan disediakannya tenda-tenda sesuai kebutuhan wisatawan.

\subsubsection{Jalur Tracking dan Cycling}

Desa Wisata Kerta sangat cocok untuk dikembangkannya aktivitas tracking dan cycling karena memiliki wilayah yang cukup luas, alam dengan vegetasi yang tinggi, topografi landai dan berbukit-bukit serta banyak lembah dan didukung dengan infrastruktur jalan yang cukup memadai. Kondisi ini menjadi pemandangan menarik untuk wisatawan yang datang ke Desa Wisata Kerta. Aktivitas ini dapat menambah wawasan dan pengalaman wisatawan tentang lingkungan pedesaan.

Jalur tracking maupun cycling ini merupakan salah satu penunjang untuk pengembangan Desa Wisata Kerta dan hingga saat ini masih dalam tahap pengembangan serta pembukaan jalur-jalur baru. Salah satu rute Tracking maupun Cycling jalur panjang yang sudah direncanakan yaitu :

a) Dimulai dari Bumi Perkemahan Puncak Sari,

b) Kemudian ke Pura Puncak Sari,

c) Menuju Goa Gerombolan atau Kebun Raya Gianyar,

d) Dilanjutkan ke Subak Tirta Petak dan ke Subak Puseh serta air terjun,

e) Mengunjungi Banjar Bali Aga (Margatengah),

f) Melalui Jembatan Kuning dan kembali ke Bumi Perkemahan Puncak Sari.

\subsubsection{Wisata Munduk Asri}

Wisata Munduk Asri ini merupakan daya tarik wisata baru dibuka sejak bulan Oktober pada tahun 2017 yang lalu. Dimana dalam proses penggarapan daya tarik wisata ini dikerjakan dari tahun 2015. Berhubungan dengan nama Munduk Asri, dimana kata Munduk berarti gundukan tanah, sedangkan Asri berarti pemandangan yang indah. Selama pembukaan daya tarik wisata ini hingga sekarang sudah dikunjungi wisatawan.

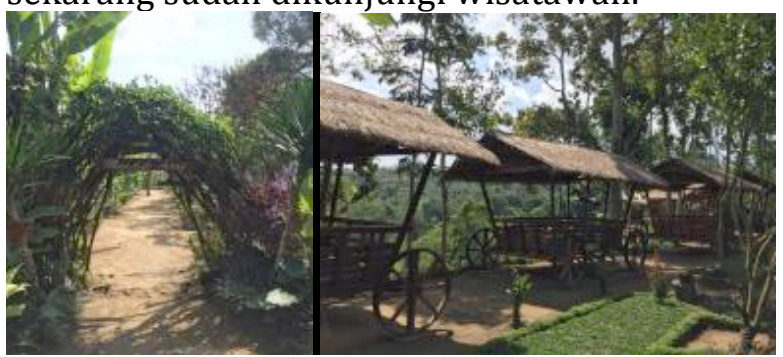

Gambar 4.10 Daya Tarik Wisata Munduk Asri Sumber : Hasil Penelitian, 2018 
Daya tarik wisata Munduk Asri ini dikelola oleh mayarakat lokal Desa Wisata Kerta yang anggota pengelolanya merupakan satu keluarga. Wisata Munduk Asri ini dibuka dari jam 8 pagi hingga jan 7 malam dengan tarif masuk sebesar Rp 15.000,- perorang. Dimana dalam perkembangannya hingga saat ini wisata Munduk Asri sudah memiliki kunjungan tetap selama weekday kurang lebih sekitar 50 sampai 70 orang pengunjung, sedangkan selama weekend kunjungan mencapai 100 orang bahkan lebih. Kegiatan yang biasanya dilakukan dominan berupa untuk berfoto, berkumpul bersama keluarga, prewedding, menghilangkan penat dari kehidupan sehari-hari dan lain sebagainya. Di tanah dengan luas 50 are ini akan disuguhkan dengan perkebunan jeruk milik pengelola sendiri, kebun bunga, area beristirahat seperti pondok atau bale bengong, bangunan unik berbahan bambu dan akar pohon. Serta disuguhkan dengan pemandangan seberang bukit dan jurang yang sangat indah dan yang menjadi ciri khas ikon identik Munduk Asri yaitu akar pohon Taep. Keunggulan dari daya tarik wisata Munduk Asri ini terletak pada penataan tempat dan pengolahan sumber daya yang ada di lokasi ini dengan baik dan kreatif. Menurut pengelola daya tarik wisata Munduk Asri ini adapun kendala yang mereka dapatkan selama pengembangan daya tarik wisata ini yaitu berupa akses masuk yang merupakan akses satu jalur, tempat parkir yang masih kurang memadai, penerangan, kesiapan dari pengelola sendiri dengan kunjungan yang melebihi kapasitas dan aturan-aturan yang belum ditetapkan saat memasuki daya tarik wisata Munduk Asri ini.

\section{SIMPULAN DAN SARAN \\ 5.1 Simpulan}

Adapun hasil identifikasi potensi Desa Wisata Kerta, disimpulkan bahwa potensi Desa Wisata Kerta dibagi menjadi tiga bagian yaitu potensi alam (hutan adat, hutan bambu, area persawahan, perkebunan jeruk, dan perkebunan organik yang didukung dengan nilai historis dan pemandangan yang indah), potensi budaya (situs sarkofagus, tradisi Bali Aga, dan Pura Alas Angker dengan cerita-cerita bersejarah yang sangat kental), dan potensi buatan (Bumi Perkemahan Puncak Sari, Jalur tracking dan cycling, Wisata Munduk Asri).

\subsection{Saran}

Adapun saran adalah sebagai berikut.

1) Saran kepada Pemerintah agar dalam pengembangan Desa Wisata Kerta ini dapat membantu dalam pemberian dana untuk pengembangannya dalam mengidentifikasi potensi sehingga nantinya pemerintah dapat merasakan pemasukan yang didapatkan dari kunjungan wisatawan yang datang ke Desa Wisata Kerta.

2) Saran kepada masyarakat lokal agar lebih peduli terhadap perkembangan kepariwisataan di desa dan meningkatkan kesadaran akan potensi wisata yang dimiliki oleh desa sangat melimpah serta berpartisipasi dalam pengembangannya sehingga dalam perkembangannya nanti dapat memberikan manfaat positif bagi kesejahteraan masyarakat lokal desa sendiri.

\section{DAFTAR PUSTAKA}

Anom, I Putu dan Ida Bagus Suryawan. 2016. Perkembangan dan Pengembangan Desa Wisata. Bogor : Heriya Media.

Bungin, Burhan. 2007. Analisis Data Penelitian Kualitatif. Jakarta : PT Grafindo Persada.

Cooper et. al. 1993.Tourism Principles \& Practice. England : Longman Group Limited.

Gunawan, I.M., 2016. Pengembangan Agrowisata untuk Pelestarian Budaya di Desa Kerta, Payangan Gianyar. Jurnal Master Pariwisata (JUMPA).

Suarka, F. M. (2015). Identifikasi Potensi Ekowisata Di Desa Tihingan, Kecamatan Banjarangkan, Kabupaten Klungkung. ECOTROPHIC: JurnaI Ilmu Lingkungan (Jurnal of Environmental Sciences), 6(2), 121-127.

Swarbrooke. (1996). Pengembangan Pariwisata. Jakarta: Gramedia Pustaka Utama.

Anonim, http://kerta.desa.id/ (diakses pada tanggal 21 April 2018). 